\title{
Carboxylate-bridged $\mathrm{Cu}$ (II) coordination polymeric complex: synthesis, crystal structure, magnetic properties, DNA binding and electrochemical studies
}

\author{
SABITHAKALA THATITURI ${ }^{\mathrm{a}}$, BHARGAVI GOVINDUGARI ${ }^{\mathrm{b}}$ \\ and VENKATA RAMANA REDDY CHITTIREDDY ${ }^{\mathrm{a}, *}$ \\ ${ }^{a}$ Department of Chemistry, Jawaharlal Nehru Technological University Hyderabad, Hyderabad, \\ Telangana 500 085, India \\ ${ }^{\mathrm{b}}$ School of Chemistry, University of Hyderabad, Hyderabad, Telangana 500 046, India \\ E-mail:vrr9@yahoo.com
}

MS received 12 November 2016; revised 11 May 2017; accepted 18 May 2017

\begin{abstract}
A novel water-soluble carboxylate-bridged copper(II) coordination polymer, $\mathrm{Cu}$-BIG was formed by the reaction of $\mathrm{Cu}\left(\mathrm{ClO}_{4}\right)_{2} \cdot 6 \mathrm{H}_{2} \mathrm{O}$ and tridentate benzimidazole-glycine conjugate ligand, 2-((1H-benzimidazol2-yl)methylamino) acetic acid, BIGH and its structure has been determined by IR, UV, powder XRD, VSM, CV, TGA, DTA, EPR and single crystal X-ray diffraction. Crystallographic studies indicate it to be a coordination polymer with Pī Space group. The asymmetric unit of complex contains two $\mathrm{Cu}(\mathrm{II})$ ions with elongated square pyramid geometry. The axial positions of the $\mathrm{Cu}$ (II) atoms are occupied by the carbonyl oxygen of the carboxylate group with the bond distances $\mathrm{Cu}(1)-\mathrm{O}(5)_{\text {axial }}, 2.28 \AA$, and $\mathrm{Cu}(2)-\mathrm{O}(2)_{\text {axial }}, 2.26 \AA$. The two $\mathrm{Cu}$ (II) are connected through the carboxylic group present in $\mathrm{BIGH}$, which provides electron mobilisation in the molecule and hence results in the soft ferromagnetic polymer. An in vitro antibacterial activity study of BIGH and Cu-BIG showed moderate activity against Bacillus subtilis. The DNA binding studies showed the interaction of $\mathrm{Cu}-\mathrm{BIG}$ with CT-DNA.
\end{abstract}

Keywords. Copper(II)polymeric complex; ferromagnetism; electrochemical studies; crystal structure.

\section{Introduction}

The design and synthesis of metal-organic coordination polymers (MOCPs) is an emerging area in the field of advanced materials research in recent years. ${ }^{1-4}$ The study of MOCPs is exciting due to their diverse structures, properties and compositions. Their easy customizability in addition to fascinating structural topologies has further drawn the attention of many researchers, for their potential application as advanced functional materials in the fields of catalysis, non-linear optics, medicine, etc. ${ }^{5-9}$ Consequently, many efforts have been devoted to the study of transition metalorganic coordination polymers. Especially, the MOCPs based on the $\mathrm{N}$-donor heterocycles have been widely used as luminescence materials, catalysts, electrical and magnetic materials. ${ }^{10-13}$ In view of the interesting applications, the present work has been carried

\footnotetext{
*For correspondence
}

out to synthesize a copper(II) coordination polymer of benzimidazole-glycine conjugate ligand, 2-( $(1 \mathrm{H}-$ benzimidazol-2-yl)methylamino) acetic acid, (BIGH), $\left[\left\{\mathrm{Cu}(\mathrm{BIG})\left(\mathrm{H}_{2} \mathrm{O}\right)\right\}_{2}\right]_{\mathrm{n}}\left(\mathrm{ClO}_{4}\right)_{2 \mathrm{n}} \cdot 3 \mathrm{nH}_{2} \mathrm{O}$. The BIGH consists of benzimidazole ring and carboxylic acid in its side chain, which facilitates the formation of MOCPs. ${ }^{14-18}$ Owing to its versatile coordination modes, the terminal carboxylate group acts as a bridge to construct coordination polymer. The flexible and free carboxylate terminal in BIGH is conformationally diverse to form a stable covalent bond with metal ion. The Cu-BIG coordination polymer is connected through carboxylate group, $[\mathrm{Cu}(1)-\mathrm{O}-\mathrm{C}-\mathrm{O}-\mathrm{Cu}(2)]$, which acts as a bridge for electron mobilization between two copper atoms which in turn makes a soft ferromagnetic material. The crystal structure, magnetic properties, antibacterial activity and DNA binding studies of $\mathrm{Cu}$-BIG have been carried out. The electron transfer mechanism of copper(II) complex was investigated by cyclic voltammetry. 


\section{Experimental}

\subsection{Chemicals}

All the chemicals such as iminodiacetic acid, o-phenylenediamine and Copper(II) perchlorate hexahydrate were used as obtained from Aldrich. All other chemicals and solvents used for the synthesis were reagent grade.

\subsection{Instrumentation}

IR spectrum was recorded on a JASCO FT-IR 5300 spectrometer. Elemental analysis for $\mathrm{C}, \mathrm{H}$ and $\mathrm{N}$ was done using a FLASH Ea 1112 SERIES CHNS analyzer. EPR spectrum was obtained using BRUKER Xenon EMX-ER073 spectrometer. X-ray powder diffractograms were recorded on a SMART Bruker D8 advance X-ray diffractometer using $\mathrm{Cu}-K_{\alpha} \lambda$-radiation $(\lambda=1.5406 \AA$ ) at $40 \mathrm{kV}$ and 30 $\mathrm{mA}$. Magnetic moments were recorded on Lakeshore VSM 7410. Diffuse reflectance spectra were obtained using a Shimadzu UV-3100 PC Spectrophotometer. Cyclic voltammograms were recorded using Gamry-600 electrochemical analyzer and Fluorescence measurements were made using Perkin Elmer LS45 fluorescence spectrometer. Thermo gravimetric analysis was made using Exstrar TG DTA 6300 .

\subsection{Synthesis of 2-((1H-benzimidazol-2-yl)methyla mino)acetic acid (BIGH)}

Iminodiacetic acid (15.98 g, $120.0 \mathrm{mmol})$ was dissolved in $100 \mathrm{~mL}$ of $6 \mathrm{~N} \mathrm{HCl}$, and $o-$ phenylenediamine $(3.25 \mathrm{~g}, 30.0$ $\mathrm{mmol}$ ) in $20 \mathrm{~mL}$ of $4 \mathrm{~N} \mathrm{HCl}$ was added dropwise. The reaction mass was refluxed at $100^{\circ} \mathrm{C}$ for about $16 \mathrm{~h}$. To this solution, $o$-phenylenediamine $(3.25 \mathrm{~g}, 30.0 \mathrm{mmol})$ in $20 \mathrm{~mL}$ of $4 \mathrm{~N} \mathrm{HCl}$ was added and the reaction was continued for $72 \mathrm{~h}$. The final green solution was cooled to room temperature. Green coloured precipitate obtained was filtered (dimer), and the clear brown coloured filtrate was allowed for solvent evaporation up to a minimum volume. A white solid formed was separated and dissolved in $100 \mathrm{~mL}$ of water and neutralized with $2 \mathrm{~N} \mathrm{NaOH}$; above synthesis was done based on literature procedure. ${ }^{19}$ Formed precipitate was collected and leached with cold methanol $(80 \mathrm{~mL})$ and dried in the oven. Yield: $4.7 \mathrm{~g}$ (23 mmol, 42\%). M.p. : $205-210^{\circ} \mathrm{C} ;{ }^{1} \mathrm{H}$ NMR $\left(400 \mathrm{MHz}, \mathrm{DMSO}_{-} \mathrm{d}_{6}, 25^{\circ} \mathrm{C}\right.$ ): $\delta=7.5$ (multiplet, $2 \mathrm{H}$, Ar$\mathrm{H}$ ), 7.15 (multiplet, 2H, Ar-H), 4.1 (singlet, $2 \mathrm{H}, \mathrm{CH}_{2}$ ), 3.3 (singlet, $2 \mathrm{H}, \mathrm{CH}_{2} \mathrm{COO}$ ), as shown in Figure $\mathrm{S} 3$ (Supplementary Information). IR data $\left(\mathrm{KBr}, \mathrm{cm}^{-1}\right): 3460(\mathrm{~N}-\mathrm{H}), 1643$ $(\mathrm{C}=\mathrm{O}), 1596(\mathrm{C}=\mathrm{C}$ aromatic $), 1268(\mathrm{C}-\mathrm{N})$. Anal. Calcd. $(\%)$ for (BIGH): C, 58.53; H, 5.40; N, 20.48. Found (\%): C, 58.42; H, 5.45; N, 20.36 as shown in Figure S4 (Supplementary Information).

2.3a Synthesis of copper(II) complex, Cu-BIG (1): Synthesis of $\left[\left\{\mathrm{Cu}(\mathrm{BIG})\left(\mathrm{H}_{2} \mathrm{O}\right)\right\}_{2}\right]_{\mathrm{n}}\left(\mathrm{ClO}_{4}\right)_{2 \mathrm{n}} \cdot 3 \mathrm{nH}_{2} \mathrm{O}$ was done as follows. BIGH (0.250 g, $1.12 \mathrm{mmol})$ was dissolved in $25 \mathrm{~mL}$ water, to which $5 \mathrm{~mL}$ aqueous solution of $\mathrm{Cu}\left(\mathrm{ClO}_{4}\right)_{2}$. $6 \mathrm{H}_{2} \mathrm{O}(0.45 \mathrm{~g}, 1.12 \mathrm{mmol})$ was added slowly and stirred for $5 \mathrm{~min}$. The resultant dark blue coloured solution was filtered and kept for crystallization in desiccator over $\mathrm{H}_{2} \mathrm{SO}_{4}$. Good quality blue coloured single crystals obtained were collected after seven days. Yield: $0.72 \mathrm{~g}(0.87 \mathrm{mmol}, 72 \%)$. IR data $\left(\mathrm{KBr}, \mathrm{cm}^{-1}\right)$ : 3435 (bound water), $3249(\mathrm{~N}-\mathrm{H}), 3228$ (Ar$\mathrm{H}), 1615(\mathrm{C}=\mathrm{O}), 1285(\mathrm{C}-\mathrm{N})$.

\section{$2.4 X$-ray crystal structure determination}

$\mathrm{X}$-ray diffraction data were collected for $\mathrm{Cu}-\mathrm{BIG}$ complex on a BRUKER-AXS SMART APEX CCD X-ray diffractometer, using graphite-monochromatic Mo $\mathrm{K} \alpha$ radiation $(=0.71073$ $\AA$ ). Data were reduced using SAINTPLUS ${ }^{20}$ and a multi-scan absorption correction using SADABS ${ }^{21}$ was performed. The structures were solved using SHELXS-97 ${ }^{22}$ and full matrix least-squares refinements against $\mathrm{F}^{2}$ were carried out using SHELXL-97. ${ }^{23}$ All ring hydrogen atoms were assigned on the basis of geometrical considerations and were allowed to ride upon the respective carbon atoms. All hydrogen atoms were assigned fixed $\mathrm{U}_{\text {iso }}$ values, equal to $1.2 \mathrm{U}_{\mathrm{eq}}$ of the parent atom for ring and $1.5 \mathrm{U}_{\mathrm{eq}}$ for methyl hydrogens. Crystallographic data and structure refinement parameters are presented in Table 1.

Table 1. Crystal data and structure refinement details for $\mathrm{Cu}-\mathrm{BIG}$.

\begin{tabular}{|c|c|}
\hline Formula & $\mathrm{C}_{20} \mathrm{H}_{30} \mathrm{Cl}_{2} \mathrm{Cu}_{2} \mathrm{~N}_{6} \mathrm{O}_{17}$ \\
\hline Formula weight & 824.48 \\
\hline Crystal system & Triclinic \\
\hline$a(\AA)$ & $7.0044(8)$ \\
\hline$b(\AA)$ & $11.8269(13)$ \\
\hline$c(\AA)$ & $18.495(2)$ \\
\hline$\alpha\left(\left(^{0}\right)\right.$ & $88.306(2)$ \\
\hline$\beta\left(^{\circ}\right)$ & $85.763(2)$ \\
\hline$\gamma\left({ }^{\circ}\right)$ & $84.972(2)$ \\
\hline$V\left(\AA^{3}\right)$ & $1521.7(3)$ \\
\hline Space group & $P_{\overline{1}}$ \\
\hline$Z$ & 2 \\
\hline$T(\mathrm{~K})$ & $298(2)$ \\
\hline$\rho_{\text {calcd }}\left(\mathrm{g} \mathrm{cm}^{-3}\right)$ & 1.799 \\
\hline$\mu\left(\mathrm{mm}^{-1}\right)$ & 1.661 \\
\hline$\theta$ Range $\left({ }^{\circ}\right)$ & $1.10-28.26$ \\
\hline$h / k / l$ indices & $-9,9 /-15,15 /-24,24$ \\
\hline Reflections collected & 17733 \\
\hline Unique reflection, $R_{\text {int }}$ & $7083,0.0285$ \\
\hline GooF & 1.038 \\
\hline$R_{1}[I>2 \sigma(I)]$ & 0.0509 \\
\hline$w R_{2}$ [all data] & 0.1329 \\
\hline$\Delta \rho_{\max }, \Delta \rho_{\min }\left(\mathrm{e} \cdot \AA^{-3}\right)$ & $1.069,-0.542$ \\
\hline
\end{tabular}




\section{Results and Discussion}

\subsection{Crystal structure of $\left[\mathrm{Cu}(\mathrm{BIG})\left(\mathrm{H}_{2} \mathrm{O}\right)_{2}\right]_{\mathrm{n}}$ $\left(\mathrm{ClO}_{4}\right)_{2 \mathrm{n}} \cdot 3 \mathrm{nH}_{2} \mathrm{O}$}

The reaction of $\mathrm{Cu}\left(\mathrm{ClO}_{4}\right)_{2} \cdot 6 \mathrm{H}_{2} \mathrm{O}$ with the tridendate ligand, BIGH in 1:1 molar ratio in aqueous medium, upon crystallization yields blue coloured stable $\mathrm{Cu}$ (II) coordination polymeric complex (Scheme 1). Yield $75 \%$. The ORTEP ${ }^{24}$ view of the complex with the labeling of non-hydrogen atoms is shown in Figure 1. The complex, $\mathrm{Cu}$-BIG crystallizes into the triclinic system with space group $\mathrm{P} \overline{1}$. The asymmetric unit of the complex contains two $\mathrm{Cu}(\mathrm{II})$ ions with elongated square pyramid geometry. Three of the basal coordination sites of $\mathrm{Cu}$ (II) ions are occupied by the secondary amino nitrogen $(\mathrm{Cu}(1)-$ $\mathrm{N}(1), 2.01 \AA ; \mathrm{Cu}(2)-\mathrm{N}(4), 2.02 \AA)$, the imidazole nitrogen $(\mathrm{Cu}(1)-\mathrm{N}(2), 1.96 \AA ; \mathrm{Cu}(2)-\mathrm{N}(4), 1.96 \AA)$ and the carboxylate oxygen $(\mathrm{Cu}(1)-\mathrm{O}(1), 1.96 \AA$; $\mathrm{Cu}(2)-\mathrm{O}(4)$, $1.95 \AA$ ) of the ligand. The fourth position of the basal plane is occupied by neutral water molecule with the bond distance, $\mathrm{Cu}(1)-\mathrm{O}(3 \mathrm{~W}), 1.98 \AA$; $\mathrm{Cu}(2)-\mathrm{O}(6 \mathrm{~W})$, $1.97 \AA$. The axial positions of the $\mathrm{Cu}(\mathrm{II})$ ions are occupied by the carbonyl oxygen of the carboxylate group with the bond distances $\mathrm{Cu}(1)-\mathrm{O}(5)_{\text {axial }}, 2.28 \AA$; $\mathrm{Cu}(2)-$ $\mathrm{O}(2)_{\text {axial }}, 2.26 \AA$. The two $\mathrm{Cu}(\mathrm{II})$ ions are connected through the carboxyl oxygen atom of a carboxylic group and form a dimeric unit. $\mathrm{Cu}-\mathrm{BIG}$ is freely soluble in an aqueous medium due to the deprotonated ligand is which involved in the polymer formation. i.

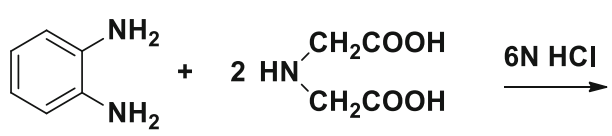

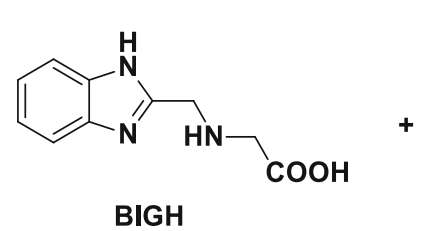

BIGH<smiles>c1ccc2[nH]c(CNCc3nc4ccccc4[nH]3)nc2c1</smiles>

Dimer

ii.
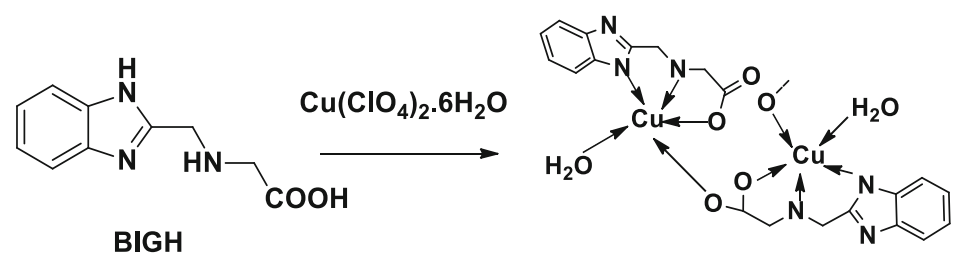

Cu-BIGH

Scheme 1. Schematic representation of the synthesis of $\mathrm{Cu}-\mathrm{BIG}$ complex.

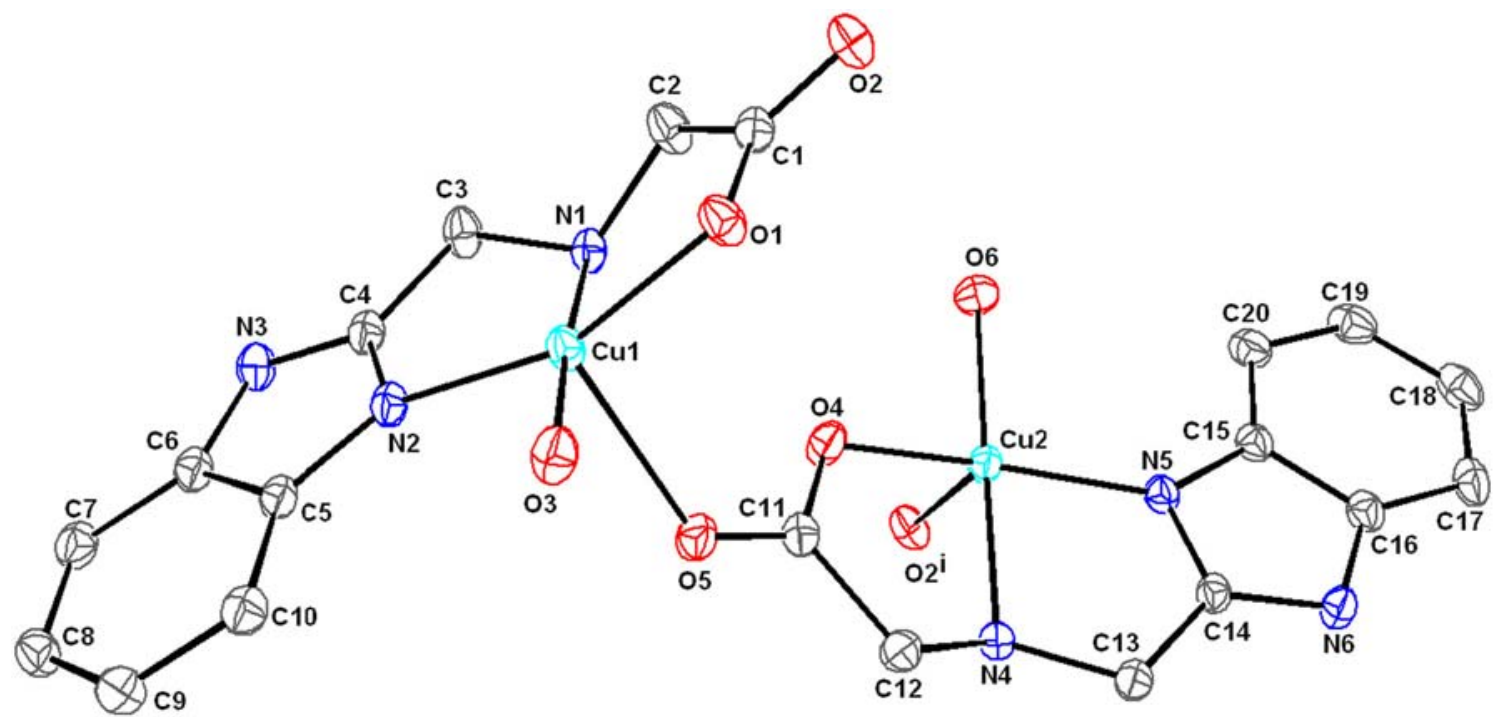

Figure 1. ORTEP view of the dimeric unit of $\left[\left\{\mathrm{Cu}(\mathrm{BIG})\left(\mathrm{H}_{2} \mathrm{O}\right)\right\}_{2}\right]_{n}\left(\mathrm{ClO}_{4}\right)_{2 n} \cdot 3 \mathrm{nH}_{2} \mathrm{O}$. Hydrogen atoms are omitted for the sake of clarity and the thermal ellipsoids are represented at the $30 \%$ probability level. Symmetry transformation $[\mathrm{i}=x-1, y, z]$. 
The dimeric units are translated along the crystallographic $a$-axis, leading to a polymeric zig-zag chain (Figure 2). Bond angles in the square plane vary from $83.0(1)^{\circ}$ to $100.8(1)^{\circ}$. The metal ion lies $0.13 \AA$ out of the least-squares basal plane, towards $\mathrm{O}(5)_{\text {axial }}$. The axial $\mathrm{Cu}-\mathrm{O}(5)$ bond is longer by 0.31
$\AA$ than the $\mathrm{Cu}-\mathrm{O}$ bond lengths in the basal plane. The molecular geometry is close to that predicted for $\mathrm{M}$ (tridentate)(monodentate) ${ }_{2}$ systems by simple donor atom repulsion theory. ${ }^{25}$ Analysis data of bond length and bond angles are listed in Tables 2 and 3. Neighbouring copper ions in the polymer are linked through

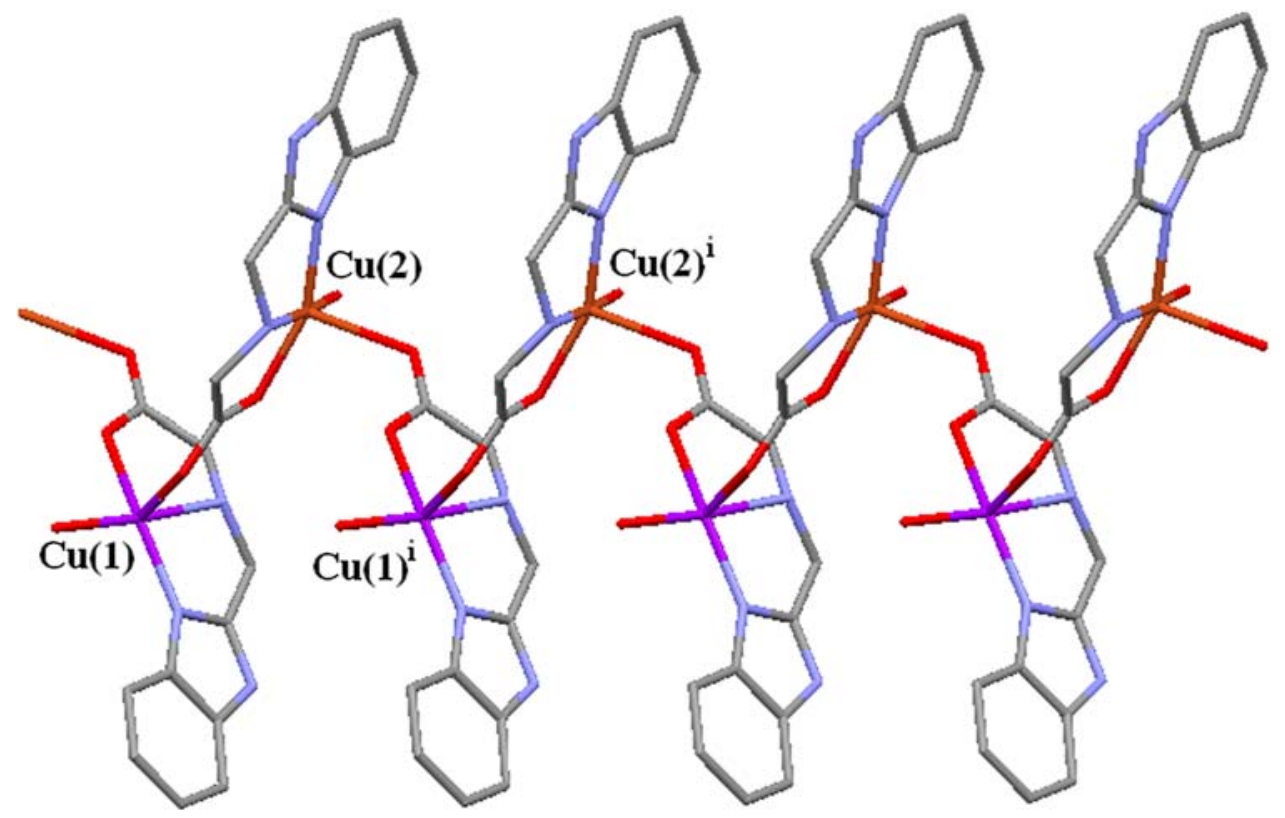

Figure 2. Perspective view of zig-zag polymeric chain of $\left[\left\{\mathrm{Cu}(\mathrm{BIG})\left(\mathrm{H}_{2} \mathrm{O}\right)\right\}_{2}\right]_{\mathrm{n}}$ $\left(\mathrm{ClO}_{4}\right)_{2 \mathrm{n}} \cdot 3 \mathrm{nH}_{2} \mathrm{O}$ along the $a$-axis $(\mathrm{i}=x-1, y, z)$. Colour code for atoms: grey $\mathrm{C} ;$ blue $\mathrm{N}$; red $\mathrm{O}$; violet $\mathrm{Cu}(1)$; brick red $\mathrm{Cu}(2)$.

Table 2. Selected bond lengths $(\AA)$ and angles $\left(^{\circ}\right)$ for $\mathrm{Cu}-\mathrm{BIG}$ complex.

\begin{tabular}{lccccc}
\hline Bond & Bond length $(\AA)$ & Bond & Bond length $(\AA)$ & Bond & Bond length $(\AA)$ \\
\hline Cu1-O1 & $1.962(2)$ & Cu2-O6 & $1.972(3)$ & Cl1-O7 & $1.438(3)$ \\
Cu1-O3 & $1.978(2)$ & Cu2-O4 & $1.949(2)$ & Cl1-O8 & $1.421(3)$ \\
Cu1-N1 & $2.011(3)$ & Cu2-N4 & $2.017(3)$ & Cl1-O9 & $1.362(5)$ \\
Cu1-N2 & $1.963(3)$ & Cu2-N5 & $1.954(3)$ & Cl1-O10 & $1.421(5)$ \\
Cu1-O5 & $2.281(2)$ & Cu2-O2\#1 & $2.254(2)$ & Cl2-O11 & $1.438(5)$ \\
Cl2-O12 & $1.367(9)$ & Cl2-O13 & $1.333(4)$ & Cl2-O14 & $1.249(5)$ \\
\hline
\end{tabular}

Symmetry transformation $=\# 1 x+1, y, z \quad \# 2 x-1, y, z$.

Table 3. Selected bond angles $\left({ }^{\circ}\right)$ for $\mathrm{Cu}-\mathrm{BIG}$ complex.

\begin{tabular}{lrcrcr}
\hline Angle & Bond angle $\left(^{\circ}\right)$ & Angle & Bond angle $\left({ }^{\circ}\right)$ & Angle & Bond angle $\left(^{\circ}\right)$ \\
\hline O1-Cu1-N1 & $83.76(11)$ & O4-Cu2-N4 & $84.66(10)$ & O4-Cu2-O2\#1 & $101.09(10)$ \\
O1-Cu1-N2 & $159.15(11)$ & O4-Cu2-06 & $93.80(11)$ & N4-Cu2-O2\#1 & $96.44(10)$ \\
O1-Cu1-O3 & $92.85(11)$ & O4-Cu2-N5 & $157.51(11)$ & O6-Cu2-O2\#1 & $87.32(11)$ \\
O1-Cu1-O5 & $98.41(10)$ & O6-Cu2-N4 & $176.14(12)$ & N5-Cu2-O2\#1 & $98.81(10)$ \\
O3-Cu1-N1 & $176.08(11)$ & N1-Cu1-O5 & $96.86(10)$ & O4-Cu2-O2\#2 & $55.68(8)$ \\
O3-Cu1-O5 & $81.67(10)$ & N5-Cu2-O6 & $97.50(11)$ & N5-Cu2-O2\#2 & $112.20(8)$ \\
N2-Cu1-O3 & $100.79(11)$ & N5-Cu2-N4 & $82.80(11)$ & O6-Cu2-O2\#2 & $65.74(9)$ \\
N2-Cu1-N1 & $83.01(11)$ & N4-Cu2-O2\#2 & $110.56(8)$ & & \\
N2-Cu1-O5 & $99.11(10)$ & O2\#1-Cu2-O2\#2 & $140.62(8)$ & & \\
\hline
\end{tabular}

Symmetry transformation $=\# 1 x+1, y, z \quad \# 2 x-1, y, z$. 


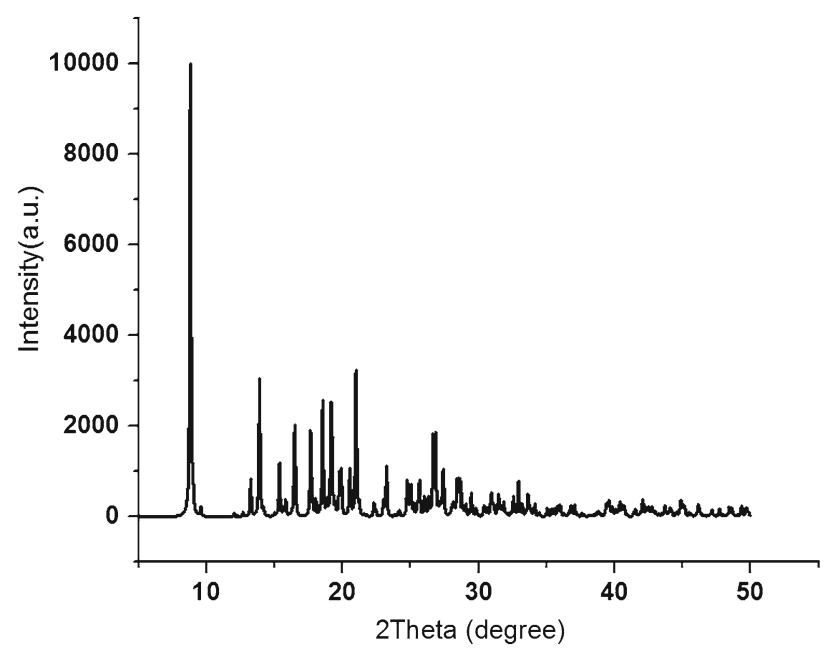

Figure 3. Powder X-ray diffraction patterns of $\mathrm{Cu}-\mathrm{BIG}$.

terminal carboxylate oxygen atoms of the ligand and form $\mathrm{a} \cdot \mathrm{Cu} \cdot \mathrm{C}-\mathrm{O}-\mathrm{C}-\mathrm{O}-\mathrm{-} \mathrm{Cu}-\mathrm{O} \cdots \mathrm{Cu} \cdot \cdots$ zigzag synanti conformational chain (Figure 3). The closest $\mathrm{Cu}$ ... Cu distance in this polymeric chain is $5.33 \AA$. The polymeric chain is additionally stabilized by the presence of hydrogen bonds involving the carboxylate oxygen, perchlorate and coordinated lattice water molecules.

\subsection{Infrared spectral analysis}

The IR spectrum of the BIGH shows several IR absorption frequencies appearing at 3462, 3013, and $2783 \mathrm{~cm}^{-1}$ due to $\mathrm{N}-\mathrm{H}$ stretching of secondary amine in the side chain, $\mathrm{N}-\mathrm{H}$ stretching imidazole ring and $\mathrm{O}-\mathrm{H}$ stretching of carboxylic acid, respectively. These frequencies are absent in the IR spectrum of the complex $\mathrm{Cu}-\mathrm{BIG}$. Thus, it confirms the involvement of nitrogen and oxygen atom in chelation with metal ion. Hence, a broad band at $3400 \mathrm{~cm}^{-1}$ indicates the presence of a water molecule in the complex, as shown in Figures S1 and S2 (Supplementary Information).

\subsection{DNA binding studies}

Generally, the DNA shows hyperchromism or hypochromism when it reacts with metal complexes. DNA binding study of the Cu-BIG complex shows hyperchromism due to the interaction of the complex with the base pairs of $\mathrm{DNA}^{26}$ through non-covalent interactions, such as $\pi-\pi$ stacking interactions, groove bindings, electrostatic interactions, hydrogen bonds and van der Waals interactions. ${ }^{27}$ This is evident from the increase in the absorbance with an increase in the DNA concentration and these binding interactions of the complex with the CT-DNA have been studied with the help of absorption spectroscopy, emission spectroscopy and by viscosity measurements.

3.3a Absorption spectroscopic studies: The absorption spectrum of $\mathrm{Cu}-\mathrm{BIG}$ complex was recorded by increasing the DNA concentration, which showed hyperchromism (Figure 4a). This is due to the interaction of the complex with DNA through van der Waals interactions. The magnitude of the hyperchromism depends on the extent of van der Waals interactions between DNA and the $\mathrm{Cu}$-BIG Complex.

The concentration of CT-DNA was calculated from Beer's law and the ratio of absorbance at 260 and 280 $\mathrm{nm}$ is between 1.8 and 1.9, which indicates that the DNA is free from protein. ${ }^{28}$ Absorption titration experiment was carried out with constant complex concentration (10 $\mu \mathrm{M}$, cuvette pathlength, $10 \mathrm{~mm}$ ) with varying DNA concentration $(0-100 \mu \mathrm{M})$ in phosphate buffer. Solution of complex and DNA was incubated at $25^{\circ} \mathrm{C}$ for $10 \mathrm{~min}$, after which absorbance readings were noted. The data was then fit into van Vleck equation ${ }^{29}$ to obtain intrinsic binding constant, $\mathrm{K}_{\mathrm{b}}$ :

$$
[\mathrm{DNA}] /\left[\varepsilon_{\mathrm{a}}-\varepsilon_{\mathrm{f}}\right]=[\mathrm{DNA}] /\left[\varepsilon_{\mathrm{b}}-\varepsilon_{\mathrm{f}}\right]+1 /\left(\mathrm{K}_{\mathrm{b}}\left[\varepsilon_{\mathrm{b}}-\varepsilon_{\mathrm{f}}\right]\right)
$$

where $\varepsilon_{\mathrm{a}}$ is the apparent extinction coefficient (A_obs/[DNA]) for each DNA + complex solution, $\varepsilon_{\mathrm{f}}$ is the extinction coefficient of the free complex and $\varepsilon_{\mathrm{b}}$ is the extinction coefficient of the fully bound complex with DNA. $\mathrm{K}_{\mathrm{b}}$ is the intrinsic binding constant. The plot of [DNA] $/\left[\varepsilon_{\mathrm{a}}-\varepsilon_{\mathrm{f}}\right]$ versus [DNA] (Figure 4(b)) gave the intrinsic binding constant, $\mathrm{K}_{\mathrm{b}}$ as a ratio of the slope to intercept. The $\mathrm{K}_{\mathrm{b}}$ for $\mathrm{Cu}-\mathrm{BIG}$ complex is $0.125 \times 10^{5} \mathrm{M}^{-1}$.

\section{3b Ethidium bromide fluorescence displacement exp-} eriments: The apparent binding constants, $\mathrm{K}_{\mathrm{app}}$ of $\mathrm{Cu}$-BIG complex was calculated by using Stern-Volmer equation. ${ }^{30}$ Fluorescence study of ethidium bromide (EtBr) bound CT DNA in the presence of a competing $\mathrm{Cu}$-BIG complex in phosphate buffer ( $\mathrm{pH}$ 7.2) was done at constant $(10 \mu \mathrm{M})$ concentration of DNA by varying the complex concentration $(10-500 \mu \mathrm{M})$. Each complex and DNA solution was incubated at $25^{\circ} \mathrm{C}$ for $10 \mathrm{~min}$, after which emission spectra were recorded. Changes in emission intensity at $600 \mathrm{~nm}$ of EtBr bound to DNA were recorded with increasing amount of the $\mathrm{Cu}$-BIGH complex concentration (Figure 5). In phosphate buffer ( $\mathrm{pH}$ 7.2), EtBr was non-emissive due to fluorescence quenching of the free EtBr by the solvent molecules. ${ }^{31,32}$ In the presence of DNA, EtBr showed enhanced emission intensity due to its intercalative binding to DNA. A 

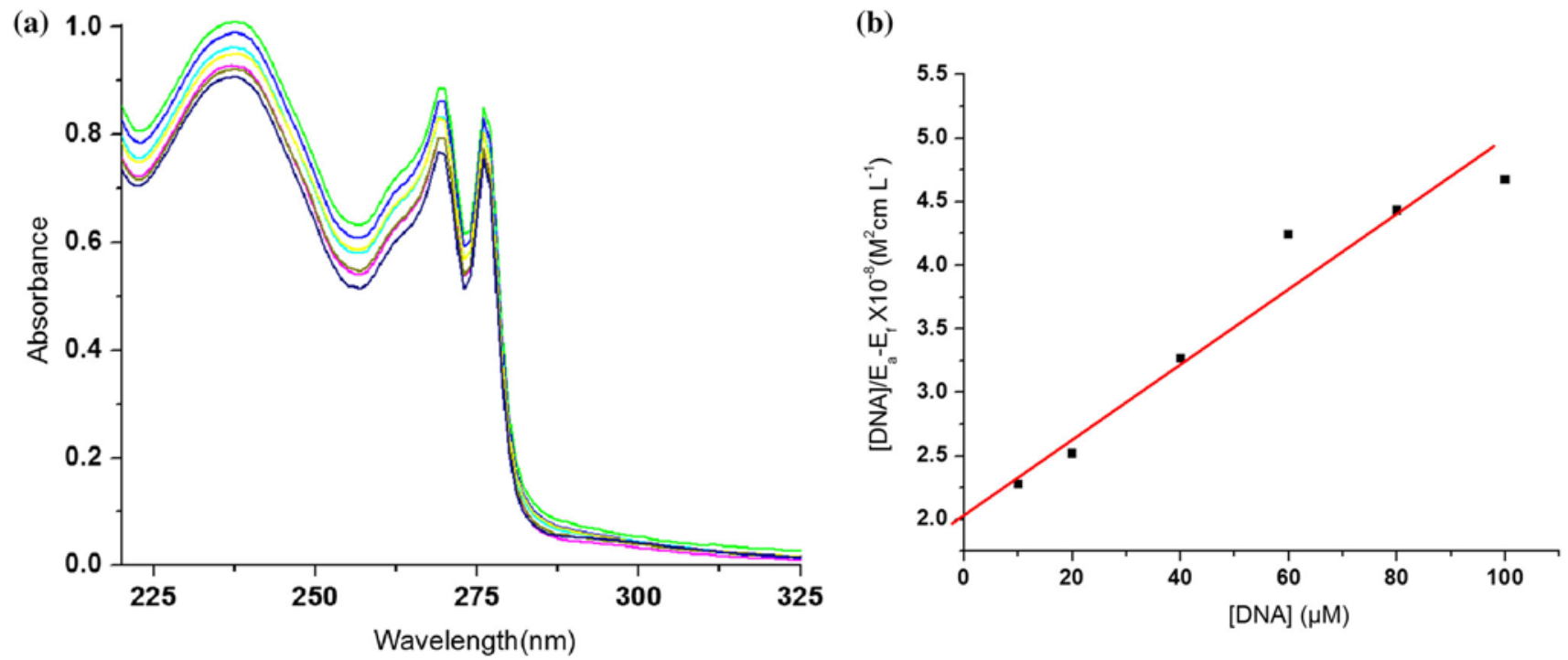

Figure 4. (a) Absorption spectra of Cu-BIG complex $(50 \mu \mathrm{M}$, cuvette pathlength, $10 \mathrm{~mm})$ for increasing concentration of DNA in phosphate buffer $\mathrm{pH}$ 7.0. (b) Plot of [DNA] $/\left[\varepsilon_{\mathrm{a}}-\varepsilon_{\mathrm{f}}\right]$ versus [DNA]. $\left(\varepsilon_{\mathrm{f}}=19968 \mathrm{M}^{-1} \mathrm{~cm}^{-1}\right)$.

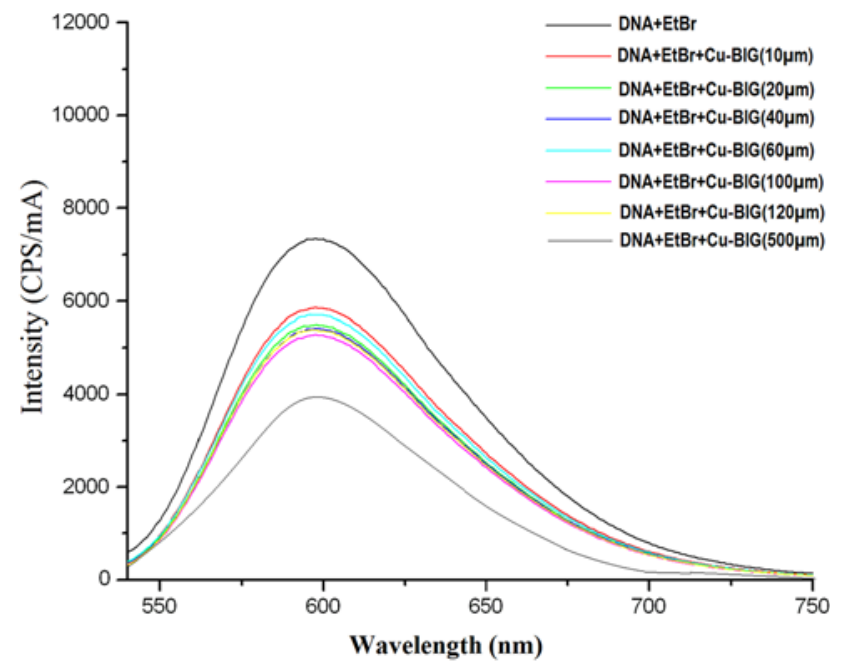

Figure 5. Emission spectra of Cu-BIG Complex, excited at $520 \mathrm{~nm}$, for varying concentrations $(10-500 \mu \mathrm{M})$.

competitive binding of the copper complex to CT DNA resulted in the displacement of the bound $\mathrm{EtBr}$, decreasing its emission intensity. The apparent binding constant $\left(\mathrm{K}_{\mathrm{app}}\right)$ was calculated from the following equation: ${ }^{33}$

$\mathrm{K}_{\mathrm{EtBr}}[\mathrm{EtBr}]=\mathrm{K}_{\mathrm{app}}[$ complex $]$

where $\mathrm{K}_{\mathrm{EtBr}}$ is $1 \times 10^{7} \mathrm{M}^{-1}$, EtBr concentration is $10 \mu \mathrm{M}$ and [complex] is the concentration of the BIGH complex, for reduction of the emission intensity of EtBr by $50 \%$. The $\mathrm{K}_{\text {app }}$ value for $\mathrm{Cu}-\mathrm{BIG}$ is $2 \times 10^{5} \mathrm{M}^{-1}$.

3.3c Viscosity measurements: Viscosity measurements were carried out using Oswald viscometer. Titrations were performed for Cu-BIG complex $(20,40,60$,
$80,100,150 \mu \mathrm{L})$ solution $(0.2 \mathrm{mM})$, which was introduced into the DNA solution $(0.25 \mathrm{mM})$. Flow time was measured with a digital stopwatch, each sample was measured thrice and an average flow time was calculated and listed in Table S1 (Supplementary Information). Data was presented as $\left(\eta / \eta_{0}\right)^{1 / 3}$ versus the ratio of the concentration of $\mathrm{Cu}-\mathrm{BIG}$ complex to DNA. ${ }^{34}$ The DNA helixes lengthen as the base pairs are separated to accommodate the binding molecule, which leads to the increase of DNA viscosity. The plots of relative viscosities are shown in Figure S6 (Supplementary Information), which show an increase in the viscosity of the complex due to the binding of $\mathrm{Cu}-\mathrm{BIG}$ with the DNA through intercalation. However, its binding ability is less when compared to classical intercalator like ethidium bromide.

$$
\left(\eta / \eta_{0}\right)^{1 / 3}=\left[\left(\left(t_{\text {complex }}-t_{0}\right) / t_{0}\right) /\left(\left(t_{\text {control }}-t_{0}\right) / t_{0}\right)\right]^{1 / 3}
$$

Here, $\eta=\left(\mathrm{t}_{\text {Complex }}-\mathrm{t}_{0}\right) / \mathrm{t}_{0}, \eta_{0}=\left(\mathrm{t}_{\text {Control }}-\mathrm{t}_{0}\right) / \mathrm{t}_{0}$, $\mathrm{t}_{\text {Complex }}=$ flow time of the complex for each titration $(20,40,60,80,100,150 \mu \mathrm{L}), \mathrm{t}_{0}=$ flow time of the pure buffer (192 s) and $t_{\text {control }}=$ flow time of the CT DNA solution (211 s).

\subsection{Magnetic properties}

The magnetic properties of the polymeric complex, $\mathrm{Cu}-\mathrm{BIG}$ have been studied using a vibrating sample magnetometer (VSM). The VSM spectrum $(\mathrm{M}-\mathrm{H})$ of magnetization $(\mu \mathrm{emu} / \mathrm{g}$ ) versus magnetic field $(\mathrm{G})$ was recorded. The $\mathrm{M}-\mathrm{H}$ measurement area ${ }^{35,36}$ and the curve 
show that it is ferromagnetic in nature with low hysteresis loss. Variation of magnetization with applied field of $\mathrm{Cu}-\mathrm{BIG}$ at $20 \mathrm{~K}$ and at room temperature are shown in the Figures 6 and 7, respectively, which show hysteresis loops of the compound measured by sweeping the external field between -1500 and $1500 \mathrm{G}$. The hysteresis loops are found to be extremely narrow. The squareness ratio for the particles is also extremely small. Narrow hysteresis loop implies that the compound is soft ferromagnetic and easier to magnetize and demagnetize in low fields. The corresponding parameters, saturation magnetization (Ms), retentivity and coercivity values obtained from the hysteresis loops are listed in Table 4. Low temperature measurements using VSM show that saturation magnetization increases with a decrease in temperature. The saturation magnetization at room tem-

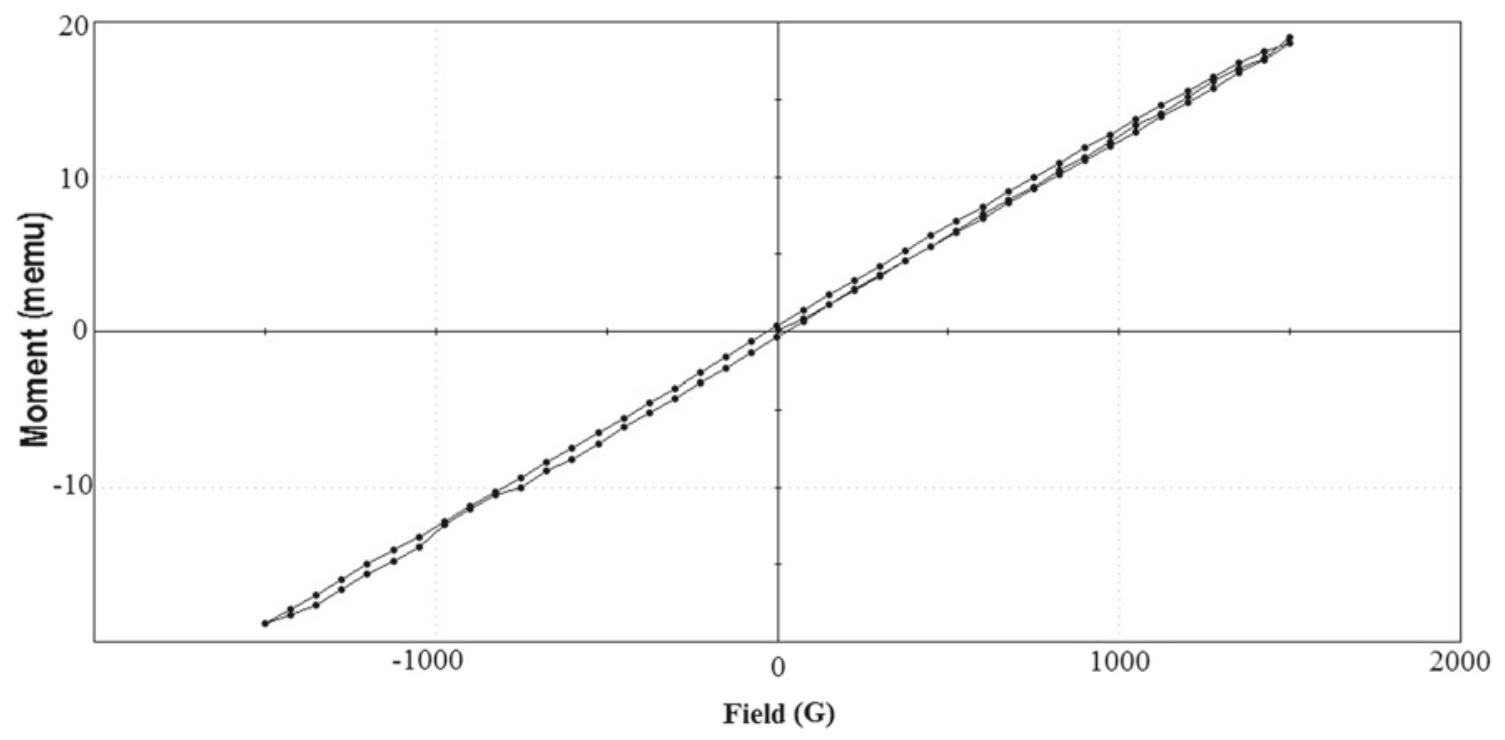

Figure 6. Variation of magnetization with applied field of $\mathrm{Cu}-\mathrm{BIG}$ complex at $20 \mathrm{~K}$.

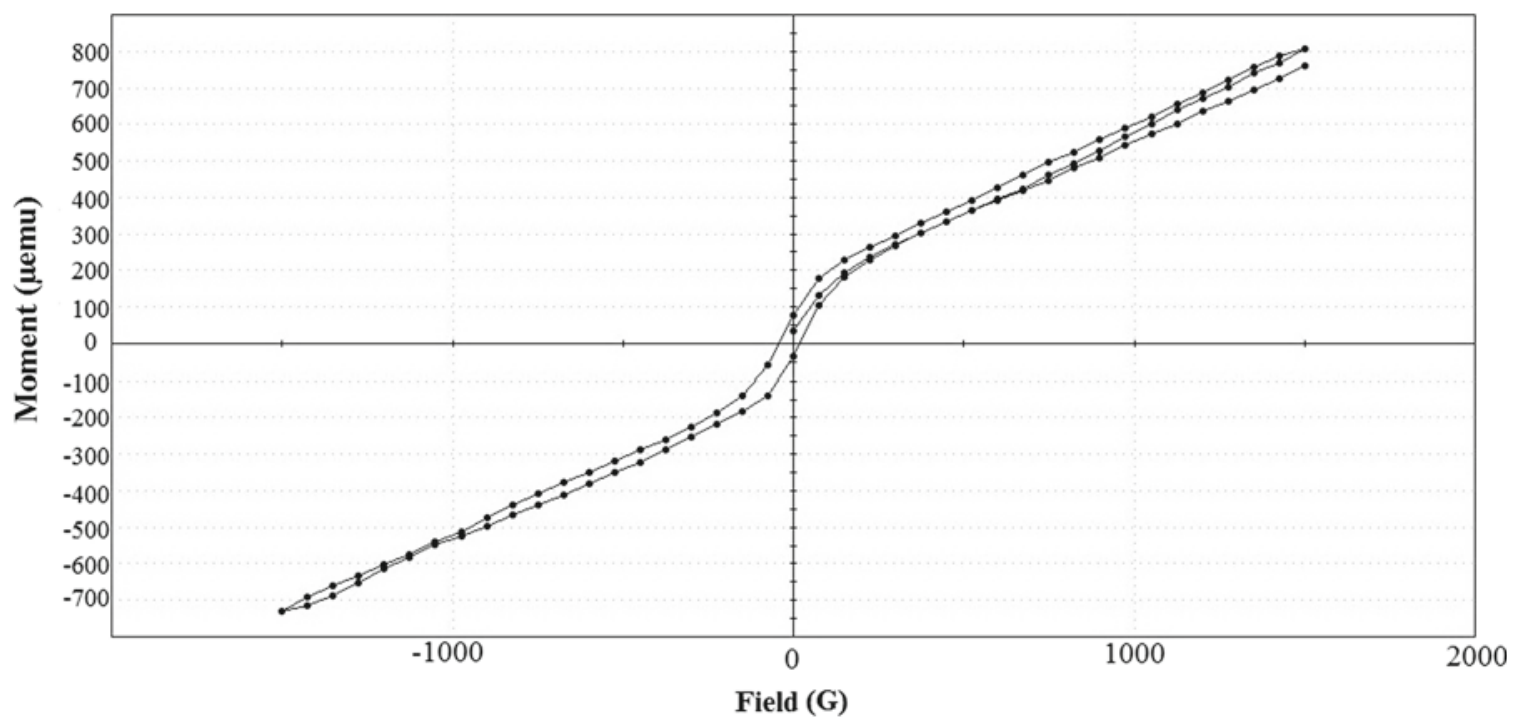

Figure 7. Variation of magnetization with applied field of $\mathrm{Cu}-\mathrm{BIG}$ complex at room temperature.

Table 4. Magnetic data of Cu-BIG complex.

\begin{tabular}{lcccc}
\hline Temperature & Sat.Mag $(\mathrm{Ms}) \mathrm{emu} / \mathrm{g}$ & Coercivity $(\mathrm{G})$ & Retentivity $(\mathrm{Mr}) \mathrm{emu} / \mathrm{g}$ & Squareness $(\mathrm{Mr} / \mathrm{Ms})$ \\
\hline $20 \mathrm{~K}$ & 0.0189 & 265.15 & $0.365 \times 10^{-3}$ & 0.0193 \\
Room temperature & $0.769 \times 10^{-3}$ & 310.79 & $0.0571 \times 10^{-3}$ & 0.0743 \\
\hline
\end{tabular}




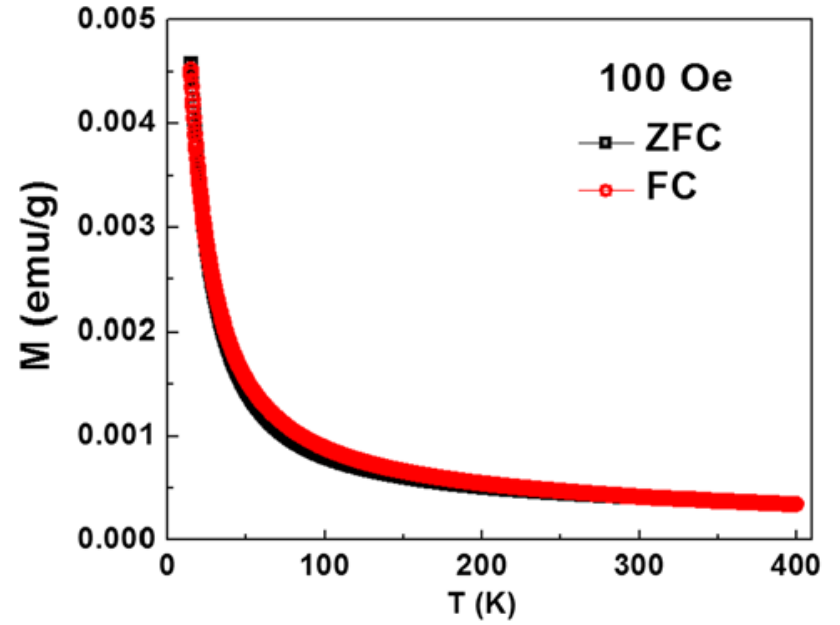

Figure 8. Magnetization versus temperature (M-T) plot of $\mathrm{Cu}-\mathrm{BIG}(1)$ at $\mathrm{H}=100 \mathrm{Oe}$.

perature is $0.769 \times 10^{-3} \mathrm{emu} / \mathrm{g}$, which increases to $0.0189 \mathrm{emu} / \mathrm{g}$ at $20 \mathrm{~K}$ and also shows an increase in coercivity with increase in temperature. As the temperature reaches the room temperature from $20 \mathrm{~K}$, soft ferromagnetic nature shifts slowly to hard ferromagnetic due to an increase in hopping length.

The magnetization as a function of temperature and magnetic field of $\mathrm{Cu}-\mathrm{BIG}$ (1) was studied using a superconducting quantum interference device (SQUID) magnetometer. Field-cooled (FC) and zero-field cooled (ZFC) magnetizations with temperature are shown in Figure 8.

Magnetic measurements of the compound were made at room temperature on a Gouy Balance. The effective magnetic moment ( $\mu_{\text {eff }}$ ) of 1 was found to be $2.088 \mathrm{BM}$. Magnetic moment of square planar $\mathrm{Cu}$ (II) complexes lies in the range of 1.70-1.90 BM.The higher value indicates distortion from square planar geometry, ${ }^{37}$ which can be inferred from the crystal structure.

\subsection{EPR studies}

The EPR spectrum of the complex was recorded at room temperature and presented in Figure 9. EPR spectrum of the complex exhibits an isotropic spectrum with $\mathrm{g}_{\text {iso }}=$ 2.121 .

\subsection{Electrochemical studies}

The redox properties of the complex were monitored by cyclic voltammetry. Cyclic voltammograms were recorded (Figures S7 and S8, in Supplementary Information) in aqueous solution with $\mathrm{Ag} / \mathrm{AgCl}$ reference electrode at the potential range, -1.2 to $+1.2 \mathrm{~V}$ in the presence of $0.1 \mathrm{M} \mathrm{KCl}$ as a supporting electrolyte. ${ }^{38,39}$ The cyclic voltammogram of $1 \mathrm{M}$ aqueous solution at

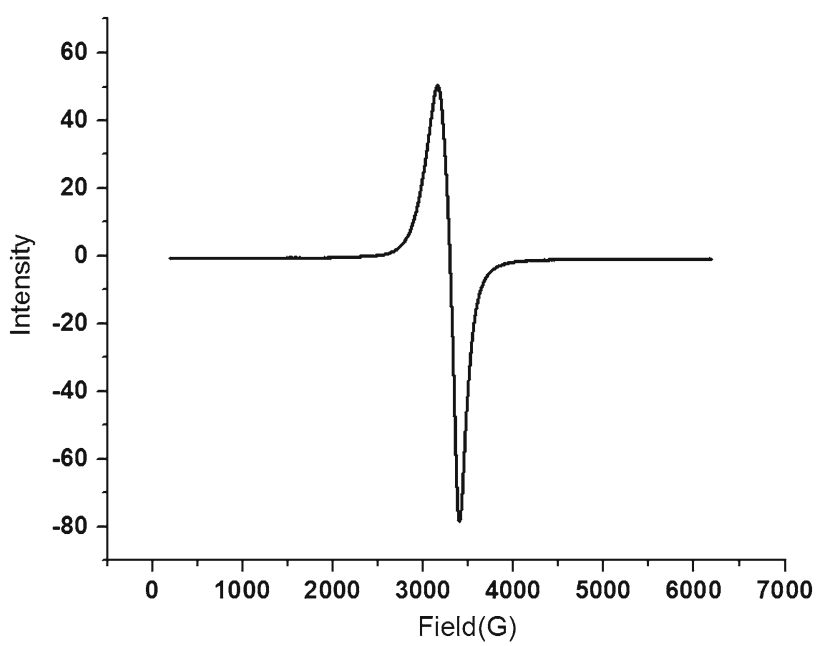

Figure 9. EPR spectrum of $\mathrm{Cu}-\mathrm{BIG}$ complex.

$200 \mathrm{mV} \mathrm{s}^{-1}$ shows only one redox peak in the studied potential range, at $+0.73 \mathrm{~V}$ for the oxidation in the forward scan and at $+0.296 \mathrm{~V}$ for the reduction peak in the reverse scan. The peak potential separation, $\Delta E=(E \mathrm{pa}-E \mathrm{pc})$, between the anodic and cathodic peaks is $434 \mathrm{mV}$. This large peak separation suggests that the reaction is quasi-reversible. The oxidation and reduction peak currents increase with the increase in scan rate. The effect of scan rate on the peak potential for the complex was also investigated by increasing the scan rate and the results are listed in Table S2 (Supplementary Information); the anodic peak potentials shift to more negative values and the cathodic peak potentials shift to more positive values. The increase in separation between the peak potentials, $\Delta \mathrm{E}$, by increasing the scan rate is a characteristic behaviour of a quasi-reversible system.

\subsection{Thermal analysis}

Thermal behaviour of the complex was studied by thermogravimetric analysis (TGA) and differential thermal analysis (DTA) recorded at $0-800^{\circ} \mathrm{C}$, as shown in Figure 10. Thermogram of the complex shows only one stage of weight loss between 250 and $275^{\circ} \mathrm{C}$ which corresponds to the decomposition of the complex and the same is evident from the exothermic DTA curve. An initial endothermic peak in DTA curve at $59-65^{\circ} \mathrm{C}$ corresponds to phase transition of the compound, second endothermic peak at $110-120^{\circ} \mathrm{C}$ corresponds to the loss of coordinated water molecule. ${ }^{40}$

\subsection{Antibacterial activity}

In vitro antibacterial activities of $\mathrm{BIGH}$ and $\mathrm{Cu}-\mathrm{BIG}$ were tested by the well-diffusion method under standard 


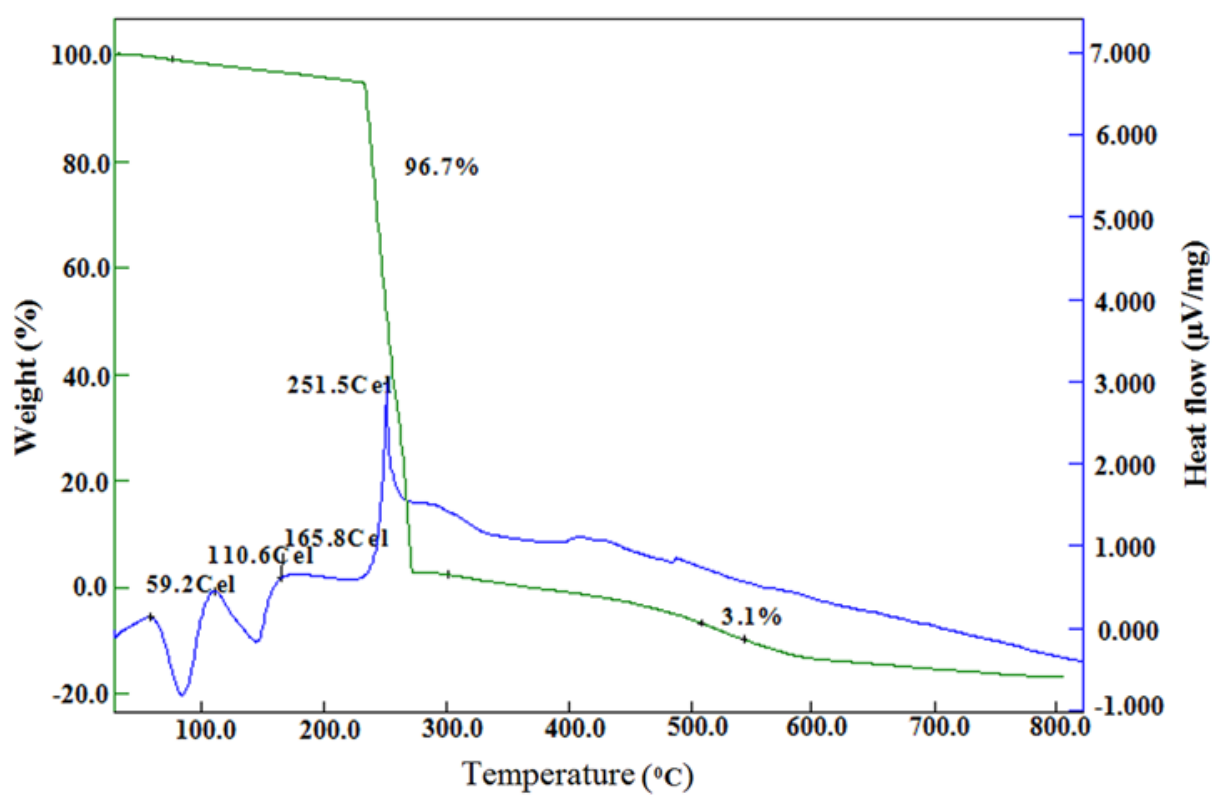

Figure 10. Thermogram of $\mathrm{Cu}-\mathrm{BIG}$ complex.

conditions. ${ }^{41}$ The strains chosen were $\mathrm{G}(+)$ Staphylococcus aureus, Bacillus subtilis and G(-)Escherichia coli and Pseudomonas aeruginosa. Bacterial subculture medium was autoclaved for $20 \mathrm{~min}$ before inoculation. Later, the bacteria were cultured for $24 \mathrm{~h}$ in an incubator at $37^{\circ} \mathrm{C}$. Nutrient agar media plates were prepared and each plate was seeded with a pure test cultures by spread plate technique. Wells were bored into the media using a sterile tip and $20 \mu \mathrm{L}$ of the test compounds $(\gamma=1 \mathrm{mg} / \mathrm{mL}$ ) was inoculated into the well by micropipette. Then the plates were incubated at $37^{\circ} \mathrm{C}$. The width of the growth inhibition zone was measured after $24 \mathrm{~h}$ of incubation. The results (Table $\mathrm{S} 3$ in SI) show that the Cu-BIG complex and BIGH are active against Bacillus subtilis and inactive against the other species. Further, the study evidently indicates that the antibacterial activity of the BIGH increased when coordinated to the $\mathrm{Cu}$ (II) ions. This is due to the greater lipophilic nature of the metal complex $(\mathrm{Cu}-\mathrm{BIG})$ than the free ligand $(\mathrm{BIGH})$.

\section{Conclusions}

The $\mathrm{Cu}$ (II) coordination polymeric complex of benzimidazole-glycine conjugate ligand, $\mathrm{Cu}$-BIG was synthesized under green conditions. Though there is no direct linkage between $\mathrm{Cu}-\mathrm{Cu}$ in the polymeric complex, in $\mathrm{Cu}-\mathrm{BIG}$ they are linked through carboxylate group of BIGH. The delocalized electron cloud of carboxylate group of BIGH induces indirect magnetic couple moments between copper ions, whereby it exhibits ferromagnetism. From the DNA binding studies, the apparent binding constant $\left(\mathrm{K}_{\mathrm{app}}\right)$ and intrinsic binding constant $\left(\mathrm{K}_{\mathrm{b}}\right)$ of $\mathrm{Cu}-\mathrm{BIG}$ were found to be $2 \times 10^{5} \mathrm{M}^{-1}$ and $0.125 \times 10^{5} \mathrm{M}^{-1}$, respectively. The cyclic voltammetric study shows that the Cu-BIG complex undergoes quasi-reversible reaction. The in vitro antibacterial activity study of $\mathrm{Cu}-\mathrm{BIG}$ indicates that it is active against Bacillus subtilis with $2.9 \mathrm{~cm}$ zone of inhibition.

\section{Supplementary Information (SI)}

CCDC 1442822 contains the supplementary crystallographic data for this paper. This data can be obtained free of charge via http://www.ccdc.cam.ac.uk/conts/retrieving.html, or from the Cambridge Crystallographic Data Center, 12 Union Road, Cambridge CB2 1EZ, UK; Fax: (+44) 1223336 033; or E-mail: deposit@ccdc.cam.ac.uk. The IR spectra of $\mathrm{BIGH}$ and $\mathrm{Cu}-\mathrm{BIG}, \mathrm{NMR}$, CHNS of BIGH, UV spectrum of Cu-BIG, Relative viscosity of Cu-BIG, Cyclic voltammograms and Crystal structure with a clear view of coordinated water (Figures S1-S9) and viscosity data of $\mathrm{Cu}-\mathrm{BIG}$, Cyclic voltammetric data for $\mathrm{Cu}-\mathrm{BIG}$ and at different scan rates and in vitro antimicrobial activity of BIGH and its copper complex (Tables S1-S3) are available in Supplementary Information at www.ias.ac.in/chemsci.

\section{Acknowledgements}

The authors are thankful to JNTU, Hyderabad and UGC networking resource centre, University of Hyderabad, India for providing necessary facilities to carry out this work.

\section{References}

1. Qin $\mathrm{J} \mathrm{H}, \mathrm{Ma} \mathrm{L} F, \mathrm{Hu} \quad \mathrm{Y}$ and Wang $\mathrm{L} \mathrm{Y}$ 2012 Syntheses, structures and photoluminescence 
of five zinc(II)coordination polymers based on 5methoxyisophthalate and flexible N-donor ancillary ligands CrystEngComm 142891

2. Yoon M, Srirambalaji R and Kim K 2012 Homochiral Metal-Organic Frameworks for Asymmetric Heterogeneous Catalysis Chem. Rev. 1121196

3. Moon H R, Lim D W and Suh M P 2013 Fabrication of metal nanoparticles in metal-organic frameworks Chem. Soc. Rev. 421807

4. Gai Y L, Jiang F L, Xiong K C, Chen L, Yuan D Q, Zhang L J, Zhou K and Hong M C 2012 TemperatureDependent in Situ Reduction of 4,4_-Azobispyridine via Solvothermal Reaction Cryst. Growth Des. 122079

5. Vishnoi P, Kalita A C and Murugavel R 2014 An anionic two-dimensional indium carboxylate framework derived from a pseudo $C_{3}$-symmetric semi-flexible tricarboxylic acid J. Chem. Sci. 1261385

6. Tripathi S, Srirambalaji R, Singh N and Anantharaman G 2014 Chiral and achiral helical coordination polymers of zinc and cadmium from achiral 2,6-bis(imidazol-1yl)pyridine: Solvent effect and spontaneous resolution $J$. Chem. Sci. 1261423

7. Janiak C 2003 Engineering coordination polymers towards applications Dalton Trans. 142781

8. Rogez G, Viart N and Drillon M 2010 Multiferroic materials: the attractive approach of metal-organic frameworks (MOFs) Angew. Chem. Int. Ed. 491921

9. Yu L, Wang Z, Wu J, Tu S and Ding K 2010 Directed Orthogonal Self-Assembly of Homochiral Coordination Polymers for Heterogeneous Enantioselective Hydrogenation Angew. Chem. Int. Ed. 493627

10. Liu B, Zhao R L, Yang G P, Hou L, Wang Y Y and Shi Q Z 2013 Two isostructural amine- unctionalized 3D selfpenetrating microporous MOFs exhibiting high sorption selectivity for CO CrystEngComm 152057

11. Liu Y Y, Li J, Ma J F, Ma J C and Yang J 2012 A 2 series of 1D, 2D and 3D coordination polymers based on a 5-(benzonic-4-ylmethoxy)isophthalic acid: Syntheses, structures and photoluminescence CrystEngComm 14169

12. Suh M P, Park H J, Prasad T K and Lim D W 2012 Hydrogen Storage in Metal-Organic Frameworks Chem. Rev. 112782

13. Cui Y J, Yue Y F, Qian G D and Chen B L 2012 Luminescent Functional Metal-Organic Frameworks Chem. Rev. 1121126

14. Zhang H M, Yang J, Liu Y Y, Kang D W and Ma J F 2015 A family of coordination polymers assembled with a flexible hexacarboxylate ligand and auxiliary $\mathrm{N}$-donor ligands: Syntheses, structures, and physical properties CrystEngComm 173181

15. Fan L M, Zhang $X \mathrm{~T}$, Sun Z, Zhang W, Ding $Y$ S, Fan W L, Sun L M, Zhao X and Lei H 2013 Ancillary Ligands Dependent Structural Diversity of A Series of Metal-Organic Frameworks Based on 3,5Bis(3-carboxyphenyl)pyridine Cryst. Growth Des. 13 2462

16. Lin L, Yu R M, Yang W B, Wu X Y and Lu C Z 2012 A Series of Chiral Metal-Organic Frameworks Basedon Oxalyl Retro-Peptides: Synthesis, Characterization, Dichroism Spectra, and Gas Adsorption Cryst. Growth Des. 123304
17. Cheng P C, Kuo P T, Liao Y H, Xie M Y, Hsu W and Chen J D 2013 Ligand-Isomerism Controlled Structural Diversity of $\mathrm{Zn}$ (II) and $\mathrm{Cd}(\mathrm{II})$ Coordination Polymers from Mixed Dipyridyladipoamide and Benzenedicarboxylate Ligands Cryst. Growth Des. 13623

18. Liu S J, Xue L, Hu T L and Bu X H 2012 Two new CoII coordination polymers based on carboxylate-bridged diand trinuclear clusters with a pyridinedicarboxylate ligand: Synthesis, structures and magnetism Dalton. Trans. 416813

19. Verweij P D, van der Geest J S N, Driessen W L, Reedijk J, Sherrington D C 1992 Metal uptake by a novel benzimidazole ligand immobilised ontopoly(glycidyl methacrylate-co-ethylene glycol dimethacrylate React. Polym. 18191

20. SAINTPLUS Software for the CCD detector System 1998 Bruker Analytical X-ray System Inc. (Madidon, WI)

21. SADABS 1998 Emperical Absorption Correction Program (Madison, Wisconsin, USA: Bruker AXS Inc)

22. Sheldrick G M 1997 Program for Crystal Structure Solution (Germany: University of Gottingen)

23. Sheldrick G M 1997 Program for Crystal Structure Refinement (Germany: University of Gottingen)

24. Farrugia L J 1997 ORTEP-3 for Windows - a version of ORTEP-III with a Graphical User Interface (GUI) J. Appl. Crystallogr. 30565

25. Kepert D L 1982 Inorganic Stereochemistry (Berlin: Springer-Verlag) p. 65

26. Patra A, Sen S, Sarkar S, Zangrando E and Chattopadhyay P 2012 Syntheses, crystal structures, and DNA-binding of some nickel(II) complexes of 1,3-bis(2pyridylmethylthio)propane and pseudohalides J. Coord. Chem. 654096

27. Bimolini Devi A 2015 Synthesis, Characterization and DNA Interaction of Metal Complex of Nitrile group Ligand International J. Basic Appl. Chem. Sci. 525

28. Reichman M E, Rice S A, Tgomas C A and Doty P 1954 A further examination of the molecular weight and size of desoxypentose nucleic acid J. Am. Chem. Soc. 763047

29. Patra A, Sarkar S, Mukherjee T, Zangrando E and Chattopadhyay P 2011 Zinc(II) complexes of 1,3-bis(2pyridylmethylthio)propane: Anion dependency, crystal structure and DNA binding study Polyhedron 302783

30. Stern O and Volmer M 1919 The extinction period of fluorescence Physik. Z. 20183

31. Waring M J 1965 Complex formation between ethidium bromide and nucleic acids J. Mol. Biol. 13269

32. Changzheng I. Jigui W, Liufang W, Min R, Naiyang J and Jie G 1999 Synthesis, characterization and antitumor activity of copper(II) complex with nicotinamido4-bis(2-chloroethyl)aminobenzaldimine J. Inorg. Biochem. 73195

33. Lee M, Rhodes A L, Wyatt M D, Forrow S and Hartley J A 1993 GC base sequence recognition by oligo(imidazolecarboxamide) and C-terminus-modified analogues of distamycin deduced from circular dichroism, proton nuclear magnetic resonance, and methidiumpropylethylenediaminetetraacetate-iron(II) footprinting studies Biochemistry 324237

34. Zhi B O, Yu Hao L, Yan Mei L, Shi Chen, Ya Hong $X$ and Xiao Hua Z 2013 A copper(II) complex with 
2-(2/-pyridyl)benzimidazole and 1-arginine: synthesis, structure, antibacterial activities, and DNA interaction J. Coord. Chem. 662152

35. Valeska da R C and Tsuneharu O 2003 Microstructure and Hysteresis Curves of Samarium-Holmium-Iron Garnet Synthesized by Coprecipitation Mat. Res. 6569

36. Chao L, Rondinone A J and Zhang Z J 2000 Synthesis of magnetic spinel ferrite $\mathrm{CoFe}_{2} \mathrm{O}_{4}$ nanoparticles from ferric salt and characterization of the size-dependent superparamagnetic properties Pure Appl. Chem. 72 37

37. Raziyeh A A and Saeid A 2012 Synthesis, Spectroscopy, Thermal Analysis, Magnetic Properties and Biological Activity Studies of $\mathrm{Cu}$ (II) and $\mathrm{Co}(\mathrm{II})$ Complexes with Schiff Base Dye Ligands Molecules 176434

38. Rong-kai P, Guo-bi Li, Sheng-gui Liu, Xiao-ping Z and Gui-zhen Y 2016 Synthesis, crystal structure, electrochemical property, and antioxidant activity of copper(II) complex based on 4-butyloxy-2,6-bis(1methyl-2-benzimidazolyl)pyridine Monatsh. Chem. 147 1189

39. Mohamed M I, Gaber A M M, Samir A E S and Abdel-Motaleb M R 2012 Synthesis, Characterization, and Electrochemical Properties of Bis(2-benzimidazolylmethyl-6-sulfonate)amine-based zinc(II), copper(II), and oxidovanadium(IV) Complexes: SOD Scavenging, DNA binding, and Anticancer Activities Int. J. Electrochem. Sci. 77526

40. Kavi Rasu K, Balaji D and Moorthy Babu S 2016 Spectroscopic properties of $\mathrm{Eu}^{3+}: \mathrm{KLa}\left(\mathrm{WO}_{4}\right)_{2}$ novel red phosphors J. Lumin. 170547

41. Souza S M, Delle-Monache F and Smânia Jr A 2005 Antibacterial Activity of Coumarins Z. Naturforsch. C 60693 